\title{
Posterior Reversible Leukoencephalopathy Syndrome Associated with Eclampsia in a Pregnant Adolescent Without Hypertension at Admission
}

\author{
Ergen Gebede Başlangıçta Hipertansiyonu OImadan Eklampsi ile Ilişkili Posterior \\ Reversible Lökoensefalopati Sendromu
}

\author{
(D) Gülsüm Uysal1, (D) Nefise Tanrıdan Okcu¹, (D) Emine Küçükbingöz¹, (D) Çağatay Küçükbingöz², (D) Esra Saygılı Yılmaz \\ ${ }^{1}$ Adana City Training and Research Hospital, Clinic of Obstetrics and Gynecology, Adana, Turkey \\ ${ }^{2}$ Adana City Training and Research Hospital, Clinic of Anesthesia and Reanimation, Adana, Turkey
}

\section{Abstract}

We report a 16-year-old primigravid Syrian patient at 30 weeks gestation who was admitted to the emergency room with tonic-clonic seizures and developed posterior reversible leukoencephalopathy syndrome (PRES) and eclampsia without high blood pressure. Diffusion-weighted magnetic resonance imaging showed PRES. Proteinuria 3+ was evidenced in catheterized urine specimen. An emergency cesarean section was immediately performed with preliminary diagnosis of eclampsia with PRES. The patient was kept in the intensive care unit and administered appropriate medicine; after which her level of consciousness improved, all neuroimaging examinations and laboratory tests returned normal. PRES may be associated with pre-eclampsia or eclampsia. High blood pressure may not always coexist with pre-eclampsia or eclampsia especially in pregnant adolescents. PRES can be reversible with appropriate treatment of the underlying cause.

Keywords: Adolescent pregnancy, eclampsia, posterior reversible leukoencephalopathy syndrome, seizures

\section{Öz}

Acil servise tonik-klonik nöbetle başvuran ve hipertansiyon öyküsü olmayan posterior reversible ensefalopati sendromu (PRES) ve eklampsi gelişen, 16 yaşında Suriyeli 30 haftalık primigravid ergen gebeyi sunmaktır. Hasta tonik klonik nöbet ile acil servise getirildi. illk değerlendirilme sonrasında 30 haftalık tek canlı gebeliği oldugu doğrulandı. Geliş tansiyon değeri 110/70 mmHg olarak değerlendirildi. Nörolojik görüntüleme için difüzyon ağırlıklı manyetik rezonans görüntüleme yapıldı ve PRES ile uyumlu bulgular rapor edildi. İdrarda 3+ proteinüri saptanması ve hastanın ajitasyonunun devam etmesi üzerine PRES eklampsi öntanısıyla acil sezaryen ile gebelik sonlandırıldı, yoğun bakıma transfer edildi. Hastanın yoğun bakım ve servis takipleri sırasında bilinci düzeldi, beyin görüntüleme ve laboratuvar testleri normale döndü, şifa ile taburcu edildi. PRES sendromu preeklampsi ve eklampsi ile eşlik edebilir. Ancak özellikle ergen gebelerde preeklampsi veya eklampsiye her zaman yüksek tansiyon eşlik etmeyebilir Bu hastalarda detaylı beyin görüntüleme ile PRES bulguları elde edilebilir. PRES altta yatan patolojinin uygun tedavisi ile tamamen geri döndürülebilir.

Anahtar Kelimeler: Ergen gebelik, eklampsi, posterior reversible ensefalopati sendromu, nöbetler

\section{Introduction}

Posterior reversible leukoencephalopathy syndrome (PRES), first described by Hinchey et al. ${ }^{1}$ in 1996 and known to be a reversible clinicoradiological syndrome, is associated with symptoms such as headache, seizures, visual changes, impaired consciousness and focal neurologic deficits. Although there are no specific diagnostic criteria for PRES, the accompanying radiological findings, including vasogenic edema mostly in the parieto-occipital regions, deep white matter and infratentorial structures, are necessary for diagnosis. 2,3

Address for Correspondence/Yazışma Adresi: Gülsüm Uysal, Adana City Training and Research Hospital, Clinic of Obstetrics and Gynecology, Adana, Turkey

E-mail: gulsumaykut@yahoo.com ORCID ID: orcid.org/0000-0002-9381-4892

Received/Geliș Tarihi: 20.06.2018 Accepted/Kabul Tarihi: 26.08.2018

${ }^{\circ}$ Copyright 2019 by Society of Pediatric Emergency and Intensive Care Medicine

Journal of Pediatric Emergency and Pediatric Intensive Care published by Galenos Yayınevi. 
Hypertensive encephalopathy, eclampsia, cytotoxic drugs and immunosuppresive treatments are risk factors for this disorder. ${ }^{4}$ The exact incidence of PRES is not known because there are only case presentations in the literature. ${ }^{5}$ Moreover, ethiopathogenesis of PRES has not been understood yet. Some of the prominent hypotheses are impaired cerebral autoregulation and endothelial dysfunction. ${ }^{1,6}$ Endothelial dysfunction has also been considered in the ethiopathogenesis of PRES particularly in patients with preeclampsia and eclampsia. Dysfunction of vascular endothelium triggers capillary leakage and disruption of the blood brain barrier ending with vasogenic edema. ${ }^{7}$ Due to blood pressure fluctuation, arteriolar constriction and dilatation alter cerebral autoregulation. ${ }^{7}$ This situation may cause breakdown of the blood brain barrier allowing extravasation of fluid into the brain parenchyma. On the other hand, focal vasoconstriction leads to local hypoperfusion, cyctotoxic edema and cerebral infarction resulting in vasogenic edema. ${ }^{8}$ Here, we report an atypical presentation of eclampsia coexisting with PRES in a 16-year-old pregnant adolescent. The association of eclampsia without hypertension at admission and PRES is discussed with radiological findings.

\section{Case Report}

A 16-year-old primigravid Syrian pregnant at 30 weeks gestation was admitted to the emergency room with tonic-clonic seizures. She did not have any systemic disease. On admission, her blood pressure was $110 / 70 \mathrm{mmHg}$ and she had psychomotor agitation with loss of consciousness and had no fever or tachycardia. Her only complaint was dizziness before presenting to the emergency department. The initial ultrasound showed an alive fetus with a gestational age of 30 weeks with normal amniotic fluid and normal fetal heart rate. Her arrival Glascow coma scale score was 12. Diffusion-weighted magnetic resonance imaging (MRI) revealed PRES involving the occipital lobe of the brain (Figure 1). Proteinuria 3+ was evidenced on catheterized urine specimen. The patient was transferred to the labor and delivery unit with the preliminary diagnosis of eclampsia and PRES and received a loading dose of $4 \mathrm{~g}$ magnesium sulfate $\left(\mathrm{MgSO}_{4}\right)$ intravenously. Serum hemoglobin level was $14.5 \mathrm{~g} / \mathrm{dL}$, and hematocrit was $43.1 \%$. Her blood biochemistry showed a normal aspartate aminotransferase (AST) level (33.7 u/L), elevated lactate dehydrogenase ( $376 \mathrm{u} / \mathrm{L}$ ), and a platelet count of $339 \times 10^{3} / \mu \mathrm{L}$. Glucose, creatinine, and serum electrolytes were within the normal range. Emergency cesarean section
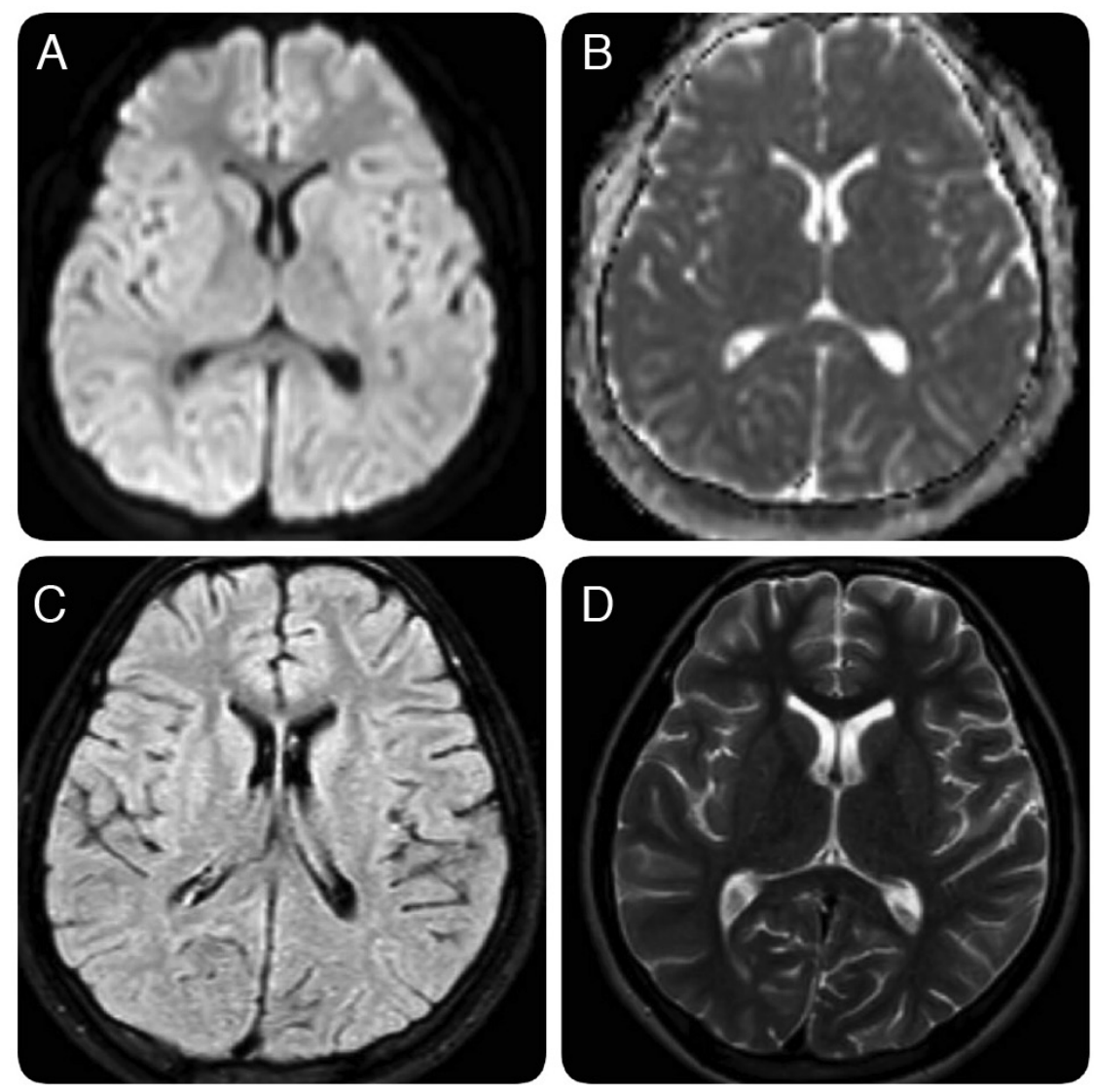

Figure 1. Radiologic images of the patient at admission (A, B) and post-treatment (C, D)

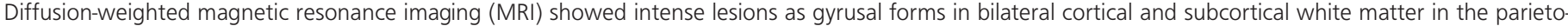

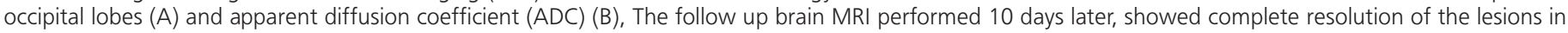
T1 sequence $(C)$, and in $T 2$ sequence (D) 
(C/S) was performed under general anesthesia. A female infant was born with a birth weight of $1150 \mathrm{~g}$ and an Apgar score of 2 at the first minute and 6 at the fifth minute. The newborn was intubated and transferred to the neonatal intensive care unit. The patient was transferred to the intensive care unit postoperatively for critical follow-up for seizures. Her mean blood pressure during surgery was $120 / 80 \mathrm{mmHg}$. After $\mathrm{C} / \mathrm{S}$, her blood pressure increased to $170 / 110 \mathrm{mmHg}$ and iv esmolol was administered. $\mathrm{MgSO}_{4} 2 \mathrm{~g}$ i.v. was also given 24 hours after delivery. On the second postoperative day, she was conscious but lethargic and could follow simple orders through an Arabic interpreter and denied visual symptoms. There was no pathology in her fundus assessment. However, she had seizures again and fluctuating mental status with postictal periods. She had psychomotor agitation and delirium and had wound dehiscence 3 days after C/S. It was re-sutured in her bed with local anesthesia. Afterwards, she received haloperidol $10 \mathrm{mg}$ i.v. $3 \times 2$ a day. Subsequently, her level of consciousness improved and psychomotor agitation decreased. Complete resolution of the edema was observed on brain MRI performed 10 day after C/S (Figure 1). She kept receiving antihypertensive medicine (amlodipine $10 \mathrm{mg} 2 \times 1$ and alfa-metil dopa $3 \times 1$ a day) for blood pressure regulation. Esmolol dose was reduced gradually and administration was stopped on the $5^{\text {th }}$ day. Postoperatively, her liver enzymes were elevated and draw a plateau (AST= minimum $=54$ - maximum $=111.3 \mathrm{u} / \mathrm{L}$ ) for 10 days. Her blood count and platelet values remained in the normal range. She stayed 10 days in the intesive care unit and was discharged home with amlodipine (10 mg daily) on postpartum day 12 without symptoms. A written informed consent was obtained from parents of the patient.

\section{Discussion}

Eclampsia includes all the symptoms of preeclampsia together with tonic-clonic seizures and plays a crucial role in the pathogenesis of PRES even in adolescent pregnancy. A maternal age younger than 20 years is one of the important risk factors for eclampsia. ${ }^{2}$ However, there is no sufficient data for prevention, management or recommendations specific to adolescent group.

Olaya-Garay et al. ${ }^{9}$ evaluated 171 patients with eclampsia and reported that $76 \%$ of patients were younger than 20 years and $46 \%$ of the patients had blood pressure lower than $140 / 90 \mathrm{~mm} \mathrm{Hg}$. They mentioned that the blood pressure value used in defining eclampsia and pre-eclampsia should be lower for adolescents especially for younger patients. Moreover, they offered re-defining diagnostic parameters for preeclampsia to be used in adults. ${ }^{9}$ In another study, 399 patients with a mean age of 19 years were evaluated and and it was found that $16 \%$ of the patients had a diastolic blood pressure of $90 \mathrm{mmHg}$ or lower. ${ }^{10}$ It was also revealed that women with postpartum eclampsia were more likely to have neurologic deficits ( $9 \%$ vs $2 \% ; p=0.006$ ) than those with antepartum eclampsia. ${ }^{10}$ In adolescence, due to the interindividual variability of uterine growth and maturation of the hypothalamic-pituitary ovarian axis, pregnancy may occur in an physically immature uterus ${ }^{11}$ This may lead to uterine overdistension, stress response in myometrium and release of inflammatory mediators. Therefore, young mothers are more likely to have eclampsia and preeclampsia.

In a recent study including 29 patients with eclampsia, it was reported that PRES appeared to accompany eclampsia in half of all cases. ${ }^{12}$ There was no significant difference in mean arterial blood pressure between patients with eclampsia and those with eclampsia and PRES. Furthermore, Liman et al. ${ }^{13}$ raported that patients with PRES and eclampsia had lower peak blood pressure compared to those with PRES of other etiologies. Particularly, children and adolescents appear to be vulnerable to PRES at lower blood pressures because of immaturity of the brain blood barrier. ${ }^{14}$

The major limitation about this paper was the lack of information about the first or second trimester follow-up during the pregnancy period.

In conclusion, adolescent pregnancy should be followed up more closely. High blood pressure may not always be present in pre-eclampsia or eclampsia especially in pregnant adolescents. PRES can be reversible with appropriate treatment of the underlying cause.

\section{Ethics}

Informed Consent: A written informed consent was obtained from parents of the patient.

Peer-review: Externally peer-reviewed.

\section{Authorship Contributions}

Surgical and Medical Practices: N.T.O., E.K., Concept: E.S.S., Design: E.S.S., Data Collection or Processing: G.U., Analysis or Interpretation: N.T.O., Literature Search: N.T.O., Writing: G.U., Ç.K.

Conflict of Interest: The author declares that there is no conflict of interest regarding the publication of this paper.

Financial Disclosure: The authors declared that this study received no financial support.

\section{References}

1. Hinchey J, Chaves C, Appignani B, Breen J, Pao L, et al. A reversible posterior leukoencephalopathy syndrome. N Engl J Med. 1996;334:494-500.

2. Schwartz RB, Feske SK, Polak JF, DeGirolami U, laia A, et al. Preeclampsia-eclampsia: clinical and neuroradiographic correlates 
and insights into the pathogenesis of hypertensive encephalopathy Radiology. 2000;217:371-6.

3. Sesar A, Cavar I, Sesar AP, Sesar I. Transient cortical blindness in posterior reversible encephalopathy syndrome after postpartum eclampsia. Taiwan J Ophthalmol. 2018;2:111-4.

4. Cozzolino M, Bianchi C, Mariani G, Marchi L, Fambrini M, et al. Therapy and differential diagnosis of posterior reversible encephalopathy syndrome (PRES) during pregnancy and postpartum. Arch Gynecol Obstet. 2015;6:1217-23.

5. Acar H, Acar K. Posterior reversible encephalopathy syndrome in a pregnant patient without eclampsia or preeclampsia: A case report. Am J Emerg Med. 2018;18:30454-6.

6. Chen Z, Zhang G, Lerner A, Wang AH, Gao B, et al. Risk factors for poor outcome in posterior reversible encephalopathy syndrome: systematic review and meta-analysis. Quant Imaging Med Surg. 2018;4:421-32.

7. Lio CF, Lee $\mathrm{YH}$, Chan HY, Yu CC, Peng NJ, et al. Posterior reversible encephalopathy syndrome in a postpartum hemorrhagic woman without hypertension: A case report. Medicine (Baltimore). 2017;96:e6690.

8. Paulson $O B$, Strandgaard S, Edvinsson L. Cerebral autoregulation. Cerebrovasc Brain Metab Rev. 1990;2:161-92.
9. Olaya-Garay SX, Velásquez-Trujillo PA, Vigil-De Gracia P. Blood pressure in adolescent patients with pre-eclampsia and eclampsia. Int J Gynaecol Obstet. 2017;138:335-9.

10. Mattar F, Sibai B. Eclampsia VIII. Risk factors for maternal morbidity. Am J Obstet Gynecol 2000;182:307-12.

11. Brosens I, Muter J, Gargett CE, Puttemans P, Benagiano G, et al. The impact of uterine immaturity on obstetrical syndromes during adolescence. Am J Obstet Gynecol. 2017;217:546-55.

12. Camara-Lemarroy $C R$, Escobedo-Zúñiga N, Villarreal-Garza E, García-Valadez E, Góngora-Rivera F, et al. Posterior reversible leukoencephalopathy syndrome (PRES) associated with severe eclampsia: Clinical and biochemical features. Pregnancy Hypertens. 2017;7:44-9.

13. Liman TG, Bohner $G$, Heuschmann PU, Scheel $M$, Endres $M$, et al. Clinical and radiological differences in posterior reversible encephalopathy syndrome between patients with preeclampsiaeclampsia and other predisposing diseases. Eur J Neurol. 2012;19:935-43.

14. Jones BV, Egelhoff JC, Patterson RJ. Hypertensive encephalopathy in children. AJNR Am J Neuroradiol. 1997;18:101-6. 